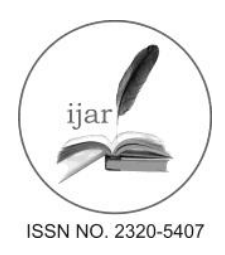

Journal homepage: http://www.journalijar.com

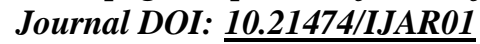

INTERNATIONAL JOURNAL

OF ADVANCED RESEARCH

RESEARCH ARTICLE

\title{
EFFECT OF BIOCHAR ON NUTRITIONAL STATUS OF SOIL.
}

\author{
*Isha Sharma ${ }^{1}$ and G.S.Rajwar ${ }^{2}$. \\ 1. Department of Botany, Government Autonomous Post Graduate College, Rishikesh 249201, Uttarakhand. \\ 2. Department of Botany, Government College, Narendranagar, Tehri Garhwal, Uttarakhand.
}

\section{Manuscript Info}

\section{Manuscript History:}

Received: 11 March 2016

Final Accepted: 15 April 2016

Published Online: May 2016

Key words:

SOC, SOM, Pyrolysis, CEC,

Exchangeable cations.

*Corresponding Author

Isha Sharma.

\begin{abstract}
Biochar is the carbonaceous material produced by the pyrolysis of organic material (plant/animal) which can be used for long term storage of $\mathrm{C}$ and as soil conditioner. The steady decrease in fertility by continuous cultivation practices is compensated by the addition of fertilizers but decrease in SOC is a serious issue. Only biochar can slow or reverse this trend. Three types of biochar viz :- pine needle biochar, poultry biochar and bagasse biochar were prepared at $500^{\circ} \mathrm{C}$. The experimental study include 6 treatment : T1 control, T2 - Pine needle biochar treatment, T3 - Poultry biochar treatment, T4 - Bagasse biochar treatment, T5 - Mixed biochar treatment and T6 - urea treatment. The effect of biochar on chemical properties were determined and it was found that biochar significantly increased the SOC, SOM, total N, available $\mathrm{P}$, available $\mathrm{K}$, exchangeable cations $-\mathrm{Ca}^{2+}, \mathrm{Mg}^{2+}$ and $\mathrm{Na}^{+}$. Micronutrients $\mathrm{Fe}$ and $\mathrm{Mn}$ increases while $\mathrm{Zn}$ decreases and $\mathrm{Cu}$ concentration was not significantly affected. The data was analyzed by applying Tukey HSD test of post hoc treatment in SPSS 16.00 Software package. Thus the study indicates that biochar can be used as a reclamation for acidic soil, increases nutrient retention, decreases need of chemical fertilizers and can be regarded as best environment friendly soil conditioner.
\end{abstract}

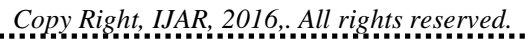

\section{Introduction:-}

The continuous cultivation practices of soil causes a steady decrease in the soil organic carbon (SOC) content and fertility. This steady decrease in fertility is compensated by addition of fertilizers but decrease in organic content is a more permanent problem. Low soil organic matter (SOM) content in soils resulting from high temperatures and rainfall are responsible for the low available water capacity and weak structure of many agricultural soils (Piccolo et $a l .$, 1996). In the past, organic amendments and polymers such as polyacrylamides (PAM) were used to improve soil physico-chemical properties and protect soils from erosion (Busscher et al., 2011). The depletion of SOM and high cost of PAM application are also serious problems to overcome. It is the need of hour to intensify agricultural crop production in order to feed current global population (Thornton et al., 2014). The field management, crop selection and solid fertilization practices will need to be modified in order to reduce crop production risks (Bozzola and Swanson, 2014; Smith et al., 2014; Wood et al., 2014). The soil nutrient pools need to become closed loop cycles simultaneously balancing source and sink of nutrients (Oktem, 2008). To cope up with above issues a new approach i.e. biochar is introduced in the agriculture field of science and technology. Biochar is the porous carbonaceous solid produced by thermo-chemical conversion of organic materials in an oxygen deficient atmosphere which has physico-chemical properties suitable for the safe and long term storage of carbon in the environment and potentially soil improvement (Shackley et al., 2010; Sohi et al., 2010). Biochar is commonly defined as charred organic matter produced with an intention of its application to soil for $\mathrm{C}$ - sequestration and for the improvement of soil properties (Lehmann and Joseph, 2009). At high temperature biochar usually becomes more alkaline as compared to lower temperature (Mukherjee et al., 2011). The ability of biochar to store carbon and improve fertility will depend on its 
physico-chemical properties which later depends on pyrolysis process and choice of feedstock (Lattao et al., 2014; Mašek et al., 2013; Zhao et al., 2013). The choice of feedstock varies from wood material, crop residue, switchgrass, organic waste, chicken litter to dairy manure, green waste and waste water sludge (Chan et al., 2008; Demirbas, 2004; Dias et al., 2010; Hossain et al., 2010; Ogawa and Okimori. 2010; Trompowsky et al., 2005; Yuan et al., 2011). Biochar physical and chemical properties influence the emergence and growth of crops in different ways (Rogovska et al., 2012; Solaiman et al., 2011). During conversion of biomass to biochar, about $50 \%$ of the original carbon is retained in the biochar which offers considerable opportunity for creating C sink (Lehmann, 2007). The recalcitrant nature of biochar suggests the presence of few components in biochar that would contribute to immobilization however biochar may adsorb organic molecules that have higher $\mathrm{C}: \mathrm{N}$ from soil solution and increase mineralization (Gundale and Deluca, 2007). Biochar created from grasses and manures (including poultry litter) appear to possess higher nutrient contents than other feedstock. The observed effects on soil fertility have been explained mainly by a ph increase in acid soils (Van Zwieten et al., 2010a) or improved nutrient retention through cation adsorption (Liang et al., 2006). Biochar as a soil amendment can improve soil quality by increasing SOM, pH, CEC and holding nutrients in soil (Zheng et al., 2010). Increased retention of $\mathrm{N}$ with biochar addition is also observed (Ding et al., 2010; Laird et al., 2010; Lehmann et al., 2003; Major et al., 2009).

\section{Methodology:-}

\section{Biochar Preparation:-}

In this study four types of biochar were prepared - pine needle biochar, poultry biochar (made from chicken manure), bagasse biochar and mixed biochar. The mixed biochar was prepared from the combination of three feedstock in equal proportion- pine needle, chicken manure and sugarcane derived bagasse. The feedstock were grinded using a grinder. Later the samples were dried at $105^{\circ} \mathrm{C}$ in an oven for 24 hours to remove surface moisture. The feedstock was then pyrolysed at $500^{\circ} \mathrm{C}$ under the recommendation of Lehmann et al. (2003) in a muffle furnace. After pyrolysis the sample was cooled, crushed and sieved with $2 \mathrm{~mm}$ mesh.

\section{Soil Sampling:-}

The soil used for experimental study was collected from Botanical Garden of Government Post Graduate College Rishikesh. The soil was collected 10-20cm below the top soil layer. The soil was air-dried for $24 \mathrm{hrs}$ and then sieved through a $2 \mathrm{~mm}$ mesh to remove plant debris, stones and other unwanted matter prior to potting. $10 \%(\mathrm{w} / \mathrm{w})$ biochar was applied according to big biochar experiment of IBI. The texture of soil was loamy sand. The chemical properties of soil used for experiment is given in table 1 .

\section{Description of experimental site:-}

The study was conducted under natural conditions from june 2014 to october 2014 and june 2015 to october 2015 at botanical garden of Government P. G College Rishikesh geographically located in the foothils of the himalayas in northern india at $30.103368^{\circ} \mathrm{N} 78.294754^{\circ} \mathrm{E}$ having average elevation of $372 \mathrm{mts}$. According to Köppen- Geiger climatic classification system, its climate is humid subtropical.

\section{Experimental Plot:-}

The study was a two year study in consecutive years to confirm the results. After applying biochar to soil the plants were grown in soil and after four months when harvesting is done the untreated and biochar treated soils were subjected to chemical analysis there were total 6 treatments given below :-

T1 - Control.

T2 - $\quad$ Pine needle biochar treatment.

T3 - Poultry biochar treatment.

T4 - Bagasse biochar treatment.

T5 - $\quad$ Mixed biochar treatment.

T6 - $\quad$ Chemical fertilizer treatment i.e urea treatment.

\section{Laboratory Analysis:-}

The soil samples before biochar treatment and after biochar treatment were subjected to chemical analysis. The $\mathrm{pH}$ and $\mathrm{EC}$ was measured by using a $\mathrm{pH}$ meter and electrical conductivity meter in a 1.2.5 soil : water ratio. Soil organic carbon was determined by Walkey- Black method and total N by Kjeldahl method (Van Reewijk, 1992). O.M can be obtained by multiplying O.C by 1.72 . The available potassium and available phosphorus was determined by ammonium acetate method(Hanway and Heidel, 1952) and olsen method (1954) respectively. The Na was determined using ammonium acetate method. The exchangeable cations $\mathrm{Ca}^{2+}$ and $\mathrm{Mg}^{2+}$ were determined using 
EDTA titration method (Cheng and Bray, 1951) and $\mathrm{Na}^{+}$by Hanway and Heidel (1952). The micronutrients Fe, Mn, $\mathrm{Zn}$ and $\mathrm{Cu}$ were determined using DTPA micronutrient extraction method (Lindsay and Norvell, 1978). S was determined using Chensen and Yien (1951) method. CEC was determined at soil pH 7 after displacement by using $1 \mathrm{~N}$ ammonium acetate method in which it was, thereafter estimated tetrimetrically by distillation of ammonium that was displaced by sodium (FAO, 1990; Rhoades and Polemio, 1977). Bicarbonate were determined by titration with $\mathrm{H}_{2} \mathrm{SO}_{4}$ while silver nitrate was used to determine chloride (Jackson, 1962). Chloride was analyzed by following the methodology of Jackson (1962).

\section{Statistical analysis of data:-}

One way analysis of variance (ANOVA) was performed to assess the significance difference in soil parameters between different treatments using the general linear model (GLM). For comparison of means in order to assess their performance regarding various treatments Tukey HSD test was applied at $p=0.05$ using SPSS 16.00 software package.

\section{Results and discussion:-}

The chemical properties of soil used for experiment are given in Table-1. The effect of biochar on chemical properties of soil in 2014 are given in Table 2 (i) and 2(ii) and the effect of biochar on chemical properties of soil in 2015 are given in Table 3 (i) and 3(ii).

Table 1: Chemical properties of soil.

\begin{tabular}{|c|c|c|}
\hline S.No & Parameter & Soil before experiment \\
\hline 1 & $\mathrm{pH}$ & $6.21 \pm 0.70$ \\
\hline 2 & $\mathrm{EC}\left(\mathrm{dsm}^{-1}\right)$ & $0.48 \pm 0.23$ \\
\hline 3 & $\mathrm{OC}(\%)$ & $0.69 \pm 0.04$ \\
\hline 4 & $\mathrm{OM}(\%)$ & $1.2 \pm 0.3$ \\
\hline 5 & Total N $(\%)$ & $0.06 \pm 0.004$ \\
\hline 6 & Available P $(\mathrm{ppm})$ & $3.7 \pm 0.41$ \\
\hline 7 & $\mathrm{Available} \mathrm{K}(\mathrm{ppm})_{0.35}$ & $126.24 \pm 1.82$ \\
\hline 8 & $\mathrm{Ca}^{2+}(\mathrm{ppm})$ & $63.10 \pm 1.47$ \\
\hline 9 & $\mathrm{Mg}^{2+}(\mathrm{ppm})$ & $54.21 \pm 0.18$ \\
\hline 10 & $\mathrm{Na}^{+}(\mathrm{ppm})$ & $78 \pm 0.12$ \\
\hline 11 & $\mathrm{~S}(\mathrm{ppm})$ & $1.35 \pm 0.2$ \\
\hline 12 & $\mathrm{Fe}(\mathrm{ppm})$ & $1.72 \pm 0.43$ \\
\hline 13 & $\mathrm{Zn}(\mathrm{ppm})$ & $0.49 \pm 0.08$ \\
\hline 14 & $\mathrm{Mn}(\mathrm{ppm})$ & $0.77 \pm 0.54$ \\
\hline 15 & $\mathrm{Cu}(\mathrm{ppm})$ & $341 \pm 0.5$ \\
\hline 16 & $\mathrm{HCO}(\mathrm{ppm})$ & $275 \pm 0.14$ \\
\hline 17 & $\mathrm{Cl}(\mathrm{ppm})$ & $0.31 \pm 0.1$ \\
\hline 18 & $\mathrm{CEC}(\mathrm{Cmol} / \mathrm{Kg})$ & \\
\hline
\end{tabular}

Table 2 (i): Effect of biochar incorporation on chemical properties of soil levelled by tukey's HSD test of post-hoc treatment analyzed by SPSS 16.00 software package.

\begin{tabular}{|l|l|l|l|l|l|c|c|c|c|}
\hline Treatment & $\mathrm{pH}$ & $\begin{array}{l}\mathrm{EC} \\
\left(\mathrm{dsm}^{-1}\right)\end{array}$ & $\begin{array}{l}\text { O.C } \\
(\%)\end{array}$ & $\begin{array}{l}\text { O.M } \\
(\%)\end{array}$ & $\begin{array}{l}\text { Total N } \\
(\%)\end{array}$ & $\begin{array}{l}\text { Available P } \\
(\mathrm{ppm})\end{array}$ & $\begin{array}{l}\text { Available K } \\
(\mathrm{ppm})\end{array}$ & $\begin{array}{l}\mathrm{Ca}^{2+} \\
(\mathrm{ppm})\end{array}$ & $\begin{array}{l}\mathrm{Mg}^{2+} \\
(\mathrm{ppm})\end{array}$ \\
\hline T1 & $6.47^{\mathrm{a}}$ & $0.51^{\mathrm{a}}$ & $0.74^{\mathrm{a}}$ & $1.30^{\mathrm{a}}$ & $0.64^{\mathrm{a}}$ & $3.60^{\mathrm{a}}$ & $80.77^{\mathrm{a}}$ & $128.21^{\mathrm{a}}$ & $61.67^{\mathrm{a}}$ \\
\hline T2 & $7.83^{\mathrm{c}}$ & $0.59^{\mathrm{bc}}$ & $2.24^{\mathrm{e}}$ & $3.84^{\mathrm{e}}$ & $0.19^{\mathrm{f}}$ & $8.90^{\mathrm{b}}$ & $406.00^{\mathrm{d}}$ & $135.11^{\mathrm{bc}}$ & $88.25^{\mathrm{b}}$ \\
\hline T3 & $8.23^{\mathrm{d}}$ & $0.63^{\mathrm{c}}$ & $1.73^{\mathrm{d}}$ & $2.98^{\mathrm{c}}$ & $0.15^{\mathrm{d}}$ & $67.77^{\mathrm{e}}$ & $719.67^{\mathrm{f}}$ & $141.62^{\mathrm{c}}$ & $104.67^{\mathrm{c}}$ \\
\hline T4 & $7.87^{\mathrm{c}}$ & $0.57^{\mathrm{bc}}$ & $1.57^{\mathrm{c}}$ & $2.67^{\mathrm{b}}$ & $0.13^{\mathrm{c}}$ & $15.3^{\mathrm{c}}$ & $267.33^{\mathrm{c}}$ & $139.57^{\mathrm{bc}}$ & $101.11^{\mathrm{c}}$ \\
\hline T5 & $7.85^{\mathrm{c}}$ & $0.58^{\mathrm{bc}}$ & $1.74^{\mathrm{d}}$ & $3.16^{\mathrm{d}}$ & $0.16^{\mathrm{e}}$ & $43.5^{\mathrm{d}}$ & $593.53^{\mathrm{e}}$ & $137.65^{\mathrm{bc}}$ & $96.34^{\mathrm{bc}}$ \\
\hline T6 & $7.17^{\mathrm{b}}$ & $0.53^{\mathrm{b}}$ & $0.83^{\mathrm{b}}$ & $1.43^{\mathrm{a}}$ & $0.74^{\mathrm{b}}$ & $9.33^{\mathrm{b}}$ & $122.00^{\mathrm{b}}$ & $131.71^{\mathrm{bc}}$ & $70.21^{\mathrm{a}}$ \\
\hline
\end{tabular}

*Figures with same alphabets are statistically at par. 
Table 2 (ii): Effect of biochar incorporation on chemical properties of soil levelled by tukey's HSD test of post-hoc treatment analyzed by SPSS 16.00 software package.

\begin{tabular}{|l|l|l|l|l|l|l|l|l|c|}
\hline Treatment & $\begin{array}{l}\mathrm{Na} \\
(\mathrm{ppm})\end{array}$ & $\begin{array}{l}\mathrm{S} \\
(\mathrm{ppm})\end{array}$ & $\begin{array}{l}\mathrm{Fe} \\
(\mathrm{ppm})\end{array}$ & $\begin{array}{l}\mathrm{Zn} \\
(\mathrm{ppm})\end{array}$ & $\begin{array}{l}\mathrm{Mn} \\
(\mathrm{ppm})\end{array}$ & $\begin{array}{l}\mathrm{Cu} \\
(\mathrm{ppm})\end{array}$ & $\begin{array}{l}\mathrm{HCO}^{3-} \\
(\mathrm{ppm})\end{array}$ & $\begin{array}{l}\mathrm{Cl}^{-} \\
(\mathrm{ppm})\end{array}$ & $\begin{array}{l}\text { CEC } \\
(\mathrm{Cmol} / \mathrm{Kg})\end{array}$ \\
\hline T1 & $51.33^{\mathrm{a}}$ & $89.00^{\mathrm{a}}$ & $1.36^{\mathrm{a}}$ & $1.75^{\mathrm{a}}$ & $0.51^{\mathrm{a}}$ & $0.83^{\mathrm{a}}$ & $346.87^{\mathrm{a}}$ & $280.00^{\mathrm{a}}$ & $0.33^{\mathrm{a}}$ \\
\hline T2 & $54.85^{\mathrm{ab}}$ & $94.12^{\mathrm{a}}$ & $2.01^{\mathrm{c}}$ & $0.88^{\mathrm{a}}$ & $0.56^{\mathrm{a}}$ & $0.94^{\mathrm{a}}$ & $351.77^{\mathrm{a}}$ & $315.00^{\mathrm{c}}$ & $1.14^{\mathrm{d}}$ \\
\hline T3 & $70.67^{\mathrm{d}}$ & $98.33^{\mathrm{a}}$ & $3.02^{\mathrm{f}}$ & $1.46^{\mathrm{a}}$ & $0.68^{\mathrm{a}}$ & $0.76^{\mathrm{a}}$ & $415.67^{\mathrm{c}}$ & $332.15^{\mathrm{d}}$ & $1.51^{\mathrm{f}}$ \\
\hline T4 & $57.33^{\mathrm{bc}}$ & $117.08^{\mathrm{b}}$ & $2.27^{\mathrm{e}}$ & $1.25^{\mathrm{a}}$ & $0.65^{\mathrm{a}}$ & $0 .^{69 \mathrm{a}}$ & $421.67^{\mathrm{c}}$ & $365.00^{\mathrm{e}}$ & $1.28^{\mathrm{e}}$ \\
\hline T5 & $61.45^{\mathrm{c}}$ & $110.15^{\mathrm{b}}$ & $2.17^{\mathrm{d}}$ & $1.74^{\mathrm{a}}$ & $0.66^{\mathrm{a}}$ & $0.71^{\mathrm{a}}$ & $389.20^{\mathrm{b}}$ & $329.12^{\mathrm{d}}$ & $0.83^{\mathrm{c}}$ \\
\hline T6 & $52.00^{\mathrm{ab}}$ & $91.14^{\mathrm{a}}$ & $1.74^{\mathrm{b}}$ & $1.52^{\mathrm{a}}$ & $0.59^{\mathrm{a}}$ & $0.84^{\mathrm{a}}$ & $352.63^{\mathrm{a}}$ & $302.40^{\mathrm{b}}$ & $0.42^{\mathrm{b}}$ \\
\hline
\end{tabular}

* Figures with same alphabets are statistically at par.

Table 3 (i): Effect of biochar incorporation on chemical properties of soil levelled by tukey's HSD test of post-hoc treatment analyzed by SPSS 16.00 software package.

\begin{tabular}{|l|l|l|l|l|l|l|l|c|c|}
\hline Treatment & $\mathrm{pH}$ & $\begin{array}{l}\mathrm{EC} \\
\left(\mathrm{dsm}^{-1}\right)\end{array}$ & $\begin{array}{l}\text { O.C } \\
(\%)\end{array}$ & $\begin{array}{l}\text { O.M } \\
(\%)\end{array}$ & $\begin{array}{l}\text { Total N } \\
(\%)\end{array}$ & $\begin{array}{l}\text { Available P } \\
(\mathrm{ppm})\end{array}$ & $\begin{array}{l}\text { Available K } \\
(\mathrm{ppm})\end{array}$ & $\begin{array}{l}\mathrm{Ca}^{2+} \\
(\mathrm{ppm})\end{array}$ & $\begin{array}{l}\mathrm{Mg}^{2+} \\
(\mathrm{ppm})\end{array}$ \\
\hline T1 & $6.67^{\mathrm{a}}$ & $0.51^{\mathrm{a}}$ & $0.80^{\mathrm{a}}$ & $1.37^{\mathrm{a}}$ & $0.06^{\mathrm{a}}$ & $3.67^{\mathrm{a}}$ & $81.30^{\mathrm{a}}$ & $131.33^{\mathrm{a}}$ & $61.33^{\mathrm{a}}$ \\
\hline T2 & $7.86^{\mathrm{c}}$ & $0.60^{\mathrm{bc}}$ & $2.24^{\mathrm{d}}$ & $3.84^{\mathrm{d}}$ & $0.19^{\mathrm{f}}$ & $8.73^{\mathrm{b}}$ & $406.33^{\mathrm{d}}$ & $138.22^{\mathrm{bc}}$ & $85.12^{\mathrm{c}}$ \\
\hline T3 & $8.17^{\mathrm{d}}$ & $0.63^{\mathrm{c}}$ & $1.74^{\mathrm{c}}$ & $2.89^{\mathrm{bc}}$ & $0.15^{\mathrm{d}}$ & $66.67^{\mathrm{e}}$ & $735.67^{\mathrm{f}}$ & $144.00^{\mathrm{d}}$ & $98.33^{\mathrm{d}}$ \\
\hline T4 & $7.95^{\mathrm{cd}}$ & $0.62^{\mathrm{bc}}$ & $1.55^{\mathrm{b}}$ & $2.69^{\mathrm{b}}$ & $0.13^{\mathrm{c}}$ & $14.63^{\mathrm{c}}$ & $266.33^{\mathrm{c}}$ & $139.62^{\mathrm{cd}}$ & $95.25^{\mathrm{d}}$ \\
\hline T5 & $7.88^{\mathrm{c}}$ & $0.61^{\mathrm{bc}}$ & $1.77^{\mathrm{c}}$ & $3.13^{\mathrm{c}}$ & $0.16^{\mathrm{e}}$ & $44.27^{\mathrm{d}}$ & $594.97^{\mathrm{e}}$ & $135.6^{\mathrm{abc}}$ & $97.10^{\mathrm{d}}$ \\
\hline T6 & $7.17^{\mathrm{b}}$ & $0.56^{\mathrm{ab}}$ & $0.87^{\mathrm{a}}$ & $1.53^{\mathrm{a}}$ & $0.07^{\mathrm{b}}$ & $9.37^{\mathrm{b}}$ & $120.73^{\mathrm{b}}$ & $133.67^{\mathrm{ab}}$ & $70.67^{\mathrm{b}}$ \\
\hline
\end{tabular}

*Figures with same alphabets are statistically at par.

Table 3 (ii): Effect of biochar incorporation on chemical properties of soil levelled by tukey's HSD test of post-hoc treatment analyzed by SPSS 16.00 software package.

\begin{tabular}{|l|l|l|l|l|l|l|l|l|c|}
\hline TREATMENT & $\begin{array}{l}\mathrm{Na} \\
(\mathrm{ppm})\end{array}$ & $\begin{array}{l}\mathrm{S} \\
(\mathrm{ppm})\end{array}$ & $\begin{array}{l}\mathrm{Fe} \\
(\mathrm{ppm})\end{array}$ & $\begin{array}{l}\mathrm{Zn} \\
(\mathrm{ppm})\end{array}$ & $\begin{array}{l}\mathrm{Mn} \\
(\mathrm{ppm})\end{array}$ & $\begin{array}{l}\mathrm{Cu} \\
(\mathrm{ppm})\end{array}$ & $\begin{array}{l}\mathrm{HCO}^{3-} \\
(\mathrm{ppm})\end{array}$ & $\begin{array}{l}\mathrm{Cl}^{-} \\
(\mathrm{ppm})\end{array}$ & $\begin{array}{l}\mathrm{CEC} \\
(\mathrm{Cmol} / \mathrm{Kg})\end{array}$ \\
\hline T1 & $52.33^{\mathrm{a}}$ & $99.15^{\mathrm{a}}$ & $1.37^{\mathrm{a}}$ & $1.83^{\mathrm{b}}$ & $0.59^{\mathrm{a}}$ & $0.91^{\mathrm{a}}$ & $360.70^{\mathrm{a}}$ & $220.67^{\mathrm{a}}$ & $0.50^{\mathrm{a}}$ \\
\hline T2 & $55.23^{\mathrm{a}}$ & $108.92^{\mathrm{b}}$ & $1.92^{\mathrm{bc}}$ & $0.85^{\mathrm{a}}$ & $0.68^{\mathrm{bc}}$ & $0.76^{\mathrm{a}}$ & $376.33^{\mathrm{b}}$ & $249.00^{\mathrm{b}}$ & $1.13^{\mathrm{d}}$ \\
\hline T3 & $72.33^{\mathrm{c}}$ & $110.20^{\mathrm{bc}}$ & $2.92^{\mathrm{d}}$ & $1.78^{\mathrm{b}}$ & $0.71^{\mathrm{c}}$ & $0.69^{\mathrm{a}}$ & $418.00^{\mathrm{d}}$ & $315.33^{\mathrm{c}}$ & $1.42^{\mathrm{f}}$ \\
\hline T4 & $56.33^{\mathrm{a}}$ & $119.60^{\mathrm{c}}$ & $2.23^{\mathrm{c}}$ & $1.13^{\mathrm{a}}$ & $0.65^{\mathrm{ab}}$ & $0.77^{\mathrm{a}}$ & $422.33^{\mathrm{d}}$ & $340.00^{\mathrm{d}}$ & $1.28^{\mathrm{e}}$ \\
\hline T5 & $63.37^{\mathrm{b}}$ & $105.06^{\mathrm{ab}}$ & $2.17^{\mathrm{c}}$ & $1.75^{\mathrm{b}}$ & $0.67^{\mathrm{bc}}$ & $0.57^{\mathrm{a}}$ & $392.00^{\mathrm{c}}$ & $329.00^{\mathrm{cd}}$ & $0.86^{\mathrm{c}}$ \\
\hline T6 & $54.33^{\mathrm{a}}$ & $101.16^{\mathrm{ab}}$ & $1.63^{\mathrm{ab}}$ & $1.61^{\mathrm{b}}$ & $0.62^{\mathrm{ab}}$ & $0.82^{\mathrm{a}}$ & $363.70^{\mathrm{a}}$ & $225.00^{\mathrm{a}}$ & $0.65^{\mathrm{b}}$ \\
\hline
\end{tabular}

* Figures with same alphabets are statistically at par.

From the perusal of Table-2(i), 2(ii), 3(i) and 3(ii), it is concluded that application of biochar of different origin showed highly significant results on chemical properties of soil. The results of present study including the effect of biochar on nutritional status of biochar are discussed in the following paragraphs:

\section{Effect of biochar application on pH and EC of soil:-}

The effect of biochar application on pH and EC of soil are given in Table-2(i) for 2014 and Table-3(i) for 2015. The statistical analysis revealed a significant increase in $\mathrm{pH}$ and $\mathrm{EC}$ in biochar amended soil. The highest $\mathrm{pH}$ was found in poultry biochar followed by pine needle biochar, bagasse biochar and mixed biochar treated soils. The study of Suppadit et al. (2012) also found an increase in $\mathrm{pH}$ and EC. An increase in soil $\mathrm{pH}$ by increasing biochar application rate might be due to the presence of alkali elements $(\mathrm{Ca}, \mathrm{Mg}$ and $\mathrm{Na})$ and the presence of - $\mathrm{OH}$ ions in biochar (Danish et al., 2015). An increase in soil $\mathrm{pH}$ following biochar application is frequently reported for across many soil types (Glaser et al., 2002; Ameloot et al., 2013a; Farrell et al., 2013; Masto et al., 2013; Stewart et al., 2013; Chintala et al., 2014b; Xu et al., 2014). The results therefore, indicate that biochar could be used as a substitution for lime materials to increase the $\mathrm{pH}$ of acidic soils. Similar increase in $\mathrm{pH}$ and EC was found by Bhattarai et al. (2015). 
According to Novak et al. (2009) presence of -OH ions in the biochar enhanced its $\mathrm{pH}$ and ultimately the soil in which biochar is applied (Bilgic and Caliskin, 2001). Yuan and Xu. (2011) also noted similar type of results on the soil $\mathrm{pH}$ when they applied the biochar in their experiment as soil amendment.

Effect of biochar on Soil Organic Carbon (SOC) and Soil Organic Matter (SOM):-

Application of biochar increases SOC significantly. The value of SOC is higher in biochar amended soil than control. In T6 treatment where urea is applied there is no increase in SOC. The high value of O.C in biochar amended soil indicate the recalcitrance of organic C in biochar. SOM follows the similar trend. High O.C in biochar amended soil samples have been reported by Lehmann. Solomon et al. (2007) and Liang et al. (2006) also revealed the higher O.C and total $\mathrm{N}$ at the ancient terra preta compared with adjacent soils. Biochar application increases SOC (Chen et al., 2008; Novak et al., 2009; Van Zwieten et al., 2010).

\section{Effect of biochar on total N:-}

The biochar treatments of different origin significantly increases the total $\mathrm{N}$. The biochar application can increase $\mathrm{N}$ availability to crops (Chan et al., 2008) and therefore high levels of SOC accumulation can enhance $\mathrm{N}$ efficiency and increase crop production (Liang et al., 2006; Pan et al., 2009). Study of Ghoneim et al. (2012) also showed an increase in total $\mathrm{N}$.

\section{Effect of biochar on available $P$ and available $K$ :-}

The available $\mathrm{P}$ and available increases significantly and found higher in poultry biochar treatment. The study of Masulili in 2010 suggested that biochar increases the available $\mathrm{P}$ in soils as biochar increases the soil $\mathrm{pH}$, which makes immobile phosphorus available. Poultry manure greatly increases the potassium content of the soil as compared to biochar (Bhattarai et al., 2015) and significant increase in exchangeable potassium was recorded by biochar application.

\section{Effect of biochar on exchangeable cations $\left(\mathrm{Ca}^{2+}, \mathrm{Mg}^{2+}\right.$ and $\left.\mathrm{Na}^{+}\right)$and $\mathrm{CEC}$ :-}

The biochar application significantly increased exchangeable cations $\left(\mathrm{Ca}^{2+}, \mathrm{Mg}^{2+}\right.$ and $\left.\mathrm{Na}^{+}\right)$and CEC. According to Lima and Marshall (2005) the release of $\mathrm{Ca}, \mathrm{K}, \mathrm{Mg}$ and $\mathrm{Na}$ ions by biochar increases the EC of soil. They argued that biochar releases these ions in soil solution through ion exchange mechanism (Tyron, 1948). Joseph et al. (2010) found that when the volatile matter is removed from the biochar then the rest biomass of biochar contains a sufficient amount of $\mathrm{Ca}, \mathrm{Mg}$ and inorganic ions in it that become the part of ash contents. Novotny et al. (2009) also reported that terra preta soils, which are previously amended by biochar, have higher $\mathrm{Ca}$ and $\mathrm{Mg}$ contents as compared to the non biochar amended soils. Shenbagavalli and Mahimairaja (2012) reported the presence of Ca and $\mathrm{Mg}$ ions in the biochar at sufficient levels that can make biochar a liming agent. According to Amonette and Joseph (2009) Biochar contains significant proportion of $\mathrm{Ca}, \mathrm{Mg}$ and $\mathrm{Na}$ that become the part of soil solution through ion exchange mechanism. Biochar has high surface area, highly porous, variable charge organic material that has the potential to increase soil CEC, surface sorption capacity and base saturation when added to soil (Glasser et al., 2002). Because $\mathrm{pH}$ increases are related to CEC increases, this benefit can be interrelated to biochars effect on soil $\mathrm{pH}$. Plants which are cultivated in biochar treated soils response better in growth through modifications in soil CEC and nutrients retention (Peng et al., 2011).

\section{effect of biochar on micronutrients ( $\mathrm{Fe}, \mathrm{Zn}, \mathrm{Mn}$ and $\mathrm{Cu})$ :-}

Iron and Manganese are associated and largely retained during biochar formation (Amonette and Joseph, 2009). Biochar application increases $\mathrm{Fe}$ and $\mathrm{Mn}$ while $\mathrm{Zn}$ decreases and $\mathrm{Cu}$ was not significantly affected. The study carried out by Gaskin et al. (2008) suggested that poultry litter biochar had highest amount of Fe where as pine chip biochar has significantly lower Fe. The study conducted by Novak et al. (2009) showed that extractable Zn marginally decreases with an increase in the addition of biochar concentration. This demonstrates that the biochar has a high sorption capacity for $\mathrm{Zn}$ where as $\mathrm{Cu}$ concentration was not significantly affected by biochar addition.

\section{Effect of biochar on Bicarbonate and Chloride ions:-}

The effect of biochar on $\mathrm{HCO}^{3-}$ and $\mathrm{Cl}^{-}$was significantly higher. According to Yuan et al (2011) the alkaline nature of biochar is developed when the $\mathrm{Na}, \mathrm{Ca}$ and $\mathrm{Mg}$ ions in biochar react with anions. These ions developed liming ability in biochar and make it preferable amendment for soil reclamation. Similar types of results were also note by Novak et al., 2009. Chintala et al. (2013) noted that Ponderosa pine wood residues biochar had higher bicarbonate 
ions that play a vital role in the extraction of soil phosphorus. Similar increase in anions was reported by Danish et al. (2015).

\section{Conclusion:-}

From the present study it is clear that biochar significantly improved the chemical properties of soil like pH, EC, O.C, O.M, N, P, K. Biochar is more stable than compost and it has a higher capacity to hold nutrients. The chemical fertilizer i.e. urea also improved soil chemical properties but it does not fulfill the aim of C-sequestration and deteriorates the soil health. Biochar can also be suggested for the reclamation of acidic soil and can be incorporate in sandy soil for improving the quality i.e., biochar reduces the acidity of soil which improves the ability of plant to adsorb most nutrients. The bicarbonate ions play major role in phosphorus extraction as well as $\mathrm{Ca}^{2+}$ and $\mathrm{Mg}^{2+}$ precipitations in soil. The long term effect of biochar on chemical properties of soil need further extensive research to identify the most cost effective and environment friendly management practice for improving soil fertility and enhancing crop production.

\section{Acknowledgement:-}

Authors are thankful to Head, Department of Botany, Government Post Graduate College, Rishikesh for providing the instrumental facility..

\section{References:-}

1. Ameloot, N., Neve, S.D., Jegajeevagan, K., Yildiz, G., Buchan, D., Funkuin, Y.N., Prins, W., Bouckaert, L. and Sleutel, S. (2013a). Short-term CO2 and N2O emissions and microbial properties of biochar amended sandy loam soils. Soil Biol. Biochem. 57: 401-410.

2. Amonette, J.E. and Joseph, S. (2009). Characteristics of biochar: microchemical properties. In: Lehmann J, Joseph S, Eds. Biochar for environmental management: science and technology., Earthscan: London. pp. 33-52

3. Bhattarai, B., Neupane, J., Dhakal, S.P., Nepal, J., Gnyawali, B., Timalsina, R. and Poudel, A.(2015). Effect of Biochar from Different Origin on Physio-Chemical Properties of Soil and Yield of Garden Pea (Pisum sativum L.) at Paklihawa, Rupandehi, Nepal. World Journal Of Agricultural Research., 3(4) : 1229 - 138.

4. Bilgic, S., Caliskan, N. (2001). An investigation of some schiff bases as corrosion inhibitors for austenitic chromium and nickel steel in $\mathrm{H}_{2} \mathrm{SO}_{4}$. J. Appl. Electrochem., 31: 79-83.

5. Bozzola, M., and Swanson, T. (2014). Policy implications of climate variability on agriculture: Water management in the Po river basin, Italy. Environ. Sci. Policy, 43: 26-38.

6. Busscher, W., Novak, J.M., Ahmedna, M. (2011). Physical effects of organic matter amendment of a southeastern US coastal loamy sand. Soil Sci., 176: 661-667.

7. Chapman, H. (1965). Cation Exchange Capacity. In: C.A. Black, (Eds.). Methods of Soil Analysis. Agronomy 9, Am. Soc. Agro. Inc., Madison, Wisconsin, pp: 891-901.

8. Chan, K.Y., Van Zwieten, L., Meszaros, I., Downie, A., Joseph, S. (2008). Using poultry litter biochars as soil amendments. Aust. J. Soil Res, 46(5):437-444.

9. Chen, B., Zhou, D. and Zhu, L. (2008) Transitional adsorption and partition of non polar and polar aromatic contaminants by biochars of pine needles with different pyrolytic temperatures. Environmental Science and Technology 42: 5137-5143.

10. Cheng, K.L. and Bray, R.H. (1951) Determination of calcium and magnesium in soil and plant material. Soil Sci., 72: 449-58.

11. Chesnin, L. and Yien, C.H. (1951). Turbidimetric determination of available sulphur. Soil a. Science Society of America Proceedings, 15:149-151.

12. Chintala, R., Schumacher, T.E., McDonald, L.M., Clay, D.E., Malo, D.D., Papiernik, S.K., $\quad$ Clay, S.A. and Julson, J.L. (2013). Phosphorus sorption and availability from biochars and soil/biochar mixtures. Soil, Air, Water, 42(5): 626-634.

13. Chintala, R., Schumacher, T.E., Kumar, S., Malo, D.D., Rice, J.A., Bleakley, B., Chilom, G., Clay, D.E., Julson, J.L., Papiernik, S.K. and Gu, Z.R. (2014b). Molecular characterization of biochars and their influence on microbiological properties of soil. J. Hazard. Mater., 279: 244-256.

14. Danish, S., Younis, U., Nasreen, S., Akhtar, N., Ehsanullah,M. and Iqbal1, M. T. (2015). Biochar consequences on cations and anions of sandy soil. Journal of Biodiversity and Environmental Sciences., 6 (2): $121-131$. 
15. Demirbas, A. (2004). Effects of temperature and particle size on bio-char yield from pyrolysis of agricultural residues. J. Anal. Appl. Pyrolysis., 72(2):243-248.

16. Dias, B.O., Silva, C.A., Higashikawa, F.S., Roig, A., Sánchez-Monedero, M.A., (2010). Use of biochar as bulking agent for the composting of poultry manure: Effect on organic matter degradation and humification. Bioresource Technology, 101(4):1239-1246.

17. Ding, Y., Liu, Y., Wu, W., Shi, D., Yang, M. and Zhong, Z. (2010). Evaluation of biochar effects on nitrogen retention and leaching in multi-layered soil columns. Water Air Soil Pollution, 213: 47-55.

18. FAO. (1990). Management of gypsiferous soils. Soils Bull. No. 62, Food and Agriculture Organization, Rome, Italy.

19. Farrell, M., Kuhn, T.K., Macdonald, L.M., Maddern, T.M., Murphy, D.V., Hall, P.A., Singh, B.P., Baumann, K., Krull, E.S. and Baldock, J.A. (2013). Microbial utilization of biochar-derived carbon. Sci. Total Environ., 465: 288-297.

20. Gaskin, J.W., Steiner, C., Harris, K., Das, K.C. and Bibens, B. (2008). Effect of low- temperature pyrolysis conditions on biochar for agricultural use. Transactions of the ASABE., 51: 2061-2069.

21. Ghoneim ,A.M., Ueno, H., Asagi, N. and Takeshi, W. (2012). Indirect $15 \mathrm{~N}$ isotope techniques for estimating $\mathrm{N}$ dynamics and $\mathrm{N}$ uptake by rice from poultry manure and $\quad$ sewage sludge. J. Asian Earth Sci., 5(2): 6369.

22. Glaser, B., Lehmann, J. and Zech, W. (2002). Ameliorating physical and chemical properties of highly weathered soils in the tropics with charcoal: a review. Biol. Fertil. Soils, 35: 219-230.

23. Gundale, M.J. and DeLuca, T.H. (2007). Temperature and source material influence on ecological attributes of ponderosa pine and Douglas-fir charcoal. For. Ecol. Manage., 231(1):86-93.

24. Hanway, J.J. and Heidel, H. (1952). Soil analysis methods as used in Iowa state college soil testing laboratory. Iowa Agri., 57: 1-31.

25. Hossain, M.K., Strezov, V., Yin Chan, K., Nelson, P.F. (2010). Agronomic properties of wastewater sludge biochar and bioavailability of metals in production of cherry tomato (Lycopersicon esculentum). Chemosphere, 78(9):1167-1171.

26. Jackson M. L. (1962). Soil Chemical analysis. Constable and Co. Ltd., London.

27. Joseph, S.D., Camps-Arbestain, M., Lin, Y., Munroe, P., Chia, C.H., Hook, J., van Zwieten, L., Kimber, S., Cowie, A., Singh, B.P., Lehmann, J., Foidl, N., Smernik, R.J. and Amonette, J.E. (2010). An investigation into the reactions of biochar in soil. Aust. J. Soil Res., 48: 501-515.

28. Laird, D., Fleming, P., Wang, B., Horton, R. and Karlen, D. (2010). Biochar impact on nutrient leaching from a mid-western agricultural soil. Geoderma, 158: 436-442.

29. Lattao, C., Cao, X., Mao, J., Schmidt-Rohr, K., and Pignatello, J. J. (2014). Influence of molecular structure and adsorbent properties on sorption of organic compounds to a temperature series of wood chars. Environ. Sci. Technol., 48: 4790-4798.

30. Lehmann, J., Da Silva, J., Steiner, C., Nehls, T., Zech, W. and Glaser B. (2003). Nutrient availability and leaching in an archaeological anthrosol and a ferralsol of the central amazon basin: Fertilizer, manure and charcoal amendments. Plant Soi., 249: 343- 357.

31. Lehmann, J. (2007). Bio-energy in the black. Frontiers in Ecology and the Environment, 5: $381-387$

32. Lehmann, J. and Joseph. (2009). Biochar for Environmental Management Science \& Technology. Earthscan, London.

33. Liang, B., J, Lehmann., D, Solomon., J, Kinyangi., J, Grossman., B, O’Nell., J,O, Skjemstad, J, Thies., F,J, Luizao,. J, Petersen. and E,G, Neves. (2006). Black carbon increases cation exchange capacity in soils. Soil Sci. Soc. Am. J., 70: 1719-1730.

34. Lima, I.M. and Marshall, W.E. (2005). Granular activated carbons from broiler manure: physical, chemical and adsorptive properties. Bioresour. Technol., 96: 699-706.

35. Lindsay, W.L. \& Norvell, W.A. (1978). Development of a DTPA soil test for zinc, iron, manganese, and copper. Soil Sci. Soc. Am. J. 42: 421-448.

36. Major, J., Lehmann, J., Rondon, M. and Goodale, C. (2009). Fate of soil-applied black carbon: downward migration, leaching and soil respiration. Global Change Biol., 1365- 2486.

37. Mašek, O., Brownsort, P., Cross, A., and Sohi, S. (2013). Influence of production conditions on the yield and environmental stability of biochar. Fuel, 103: 151-155.

38. Masulili, A., Utomo, W. H. and Syechfani, M. (2010). Rice Husk Biochar for Rice Based Cropping System in Acid Soil: The Characteristics of Rice Husk Biochar and Its Influence on the Properties of Acid Sulfate Soils and Rice Growth in West Kalimantan, Indonesia. J. Agric. Sci., 2(1): 39-47. 
39. Masto, R.M., Kumar, S., Rout, T.K., Sarkar, P., George, J. and Ram, L.C. (2013). Biochar from $\quad$ water hyacinth (Eichornia crassipes) and its impact on soil biological activity. Catena, 111: 64-71.

40. Mukherjee, A., Zimmerman, A.R. and Harris, W. (2011). Surface chemistry variations among a series of laboratory-produced biochars. Geoderma, 163: 247-255.

41. Novak, J.M., Busscher, W.J., Laird, D., Ahmedna, M., Watts, D.W. and Niandou, M.A.S. (2009). Impact of Biochar Amendment on Fertility of a Southeastern Coastal Plain Soil. Soil Sci., 174(2): 105-112.

42. Novotny, E.H., Hayes, M.H.B., Madari, B.E., Bonagamba, T.J., deAzevedo, E.R., de Souza, A.A., Song, G., Nogueira, C.M. and Mangrich, A.S. (2009). Lessons from the Terra Preta de Indios of the Amazon Region for the utilisation of charcoal for soil amendment. J. Braz. Chem. Soc., 20(6): 1003-1010.

43. Ogawa, M. and Okimori, Y. (2010). Pioneering works in biochar research, Japan. Soil Res., 48(7):489-500.

44. Oktem, A. (2008). Effect of water shortage on yield, and protein and mineral compositions of drip-irrigated sweet corn in sustainable agricultural systems. Agric. Water Manage., 95: 1003-1010.

45. Olsen, S.R., Cole, C.V., Watanable, F.S. and Dean, L.A. (1954). Estimation of available phosphorus in soils by extraction with sodium bicarbonate. Circ. U. S. Dep. Agric. 939.

46. Pan,G.X., Zhou, P., Li, Z.P., Smith, P., Li, L.Q., Qiu, D.S., Zhang, X.H., Xu, X.B., Shen, S.Y. and Chen, X.M. (2009). Combined inorganic/organic fertilization enhances $N$ efficiency and increases rice productivity through organic carbon accumulation in a rice paddy from the Tai Lake region, China. Agric. Ecos. Environ.,131: 274-280.

47. Peng, X., Ye, L.L., Wang, C.H., Shou, H. and Sun, B.( 2011). Temperature and duration dependent rice straw-derived biochar: characteristics and its effects on soil properties of an Ultisol in southern China. Soil and Tillage Research, 112: 159-166.

48. Piccolo, A., Pietramellara, G. and Mbagwu, J.S.C. (1996). Effects of coal-derived humic substances on water retention and structural stability of Mediterranean soils. Soil Use Management, 12: 209-231.

49. Rhoades, J. D., and Polemio, M. (1977). Determining cation exchange capacity: A new procedure for calcareous and gypsiferous soils. Soil Sci. Soc. Am. J., 41: $524-300$.

50. Rogovska, N., Laird, D., Cruse, R.M., Trabue, S., and Heaton, E. (2012). Emergence tests for assessing biochar quality. J Environ Qual., 41: 1014-22.

51. Shackley, S.J., Carter, S., Sims, K., Sohi, S. (2010). Expert Perceptions of the Role of Biochar as a Carbon Abatement Option with Ancillary Agronomic and Soil-related Benefits. Energy and Environment.

52. Shenbagavalli, S.S. and Mahimairaja, S. (2012). Production and characterization of biochar from different biological wastes. Int. J. Pl. and Env. Sci., 2(1): 197-201.

53. Smith, R.G., Davis, A.S., Jordan, N.R., Atwood, L.W., Daly, A.B., Grandy, A.S., Hunter, $\quad$ M.C., $\quad$ Koide, R.T., Mortensen, D.A., Ewing, P., Kane, D., Li, M., Lou, Y., Snapp, S. S., Spokas, K.A., and Yannarell, A.C. (2014). Structural equation modeling facilitates transdisciplinary research on agriculture and climate change. Crop Sci., 54: 475-483.

54. Sohi, S., Krull, E., Lopez-Capel, E., Bol, R., (2010). A Review of Biochar and Its Use and Function in Soil. Adv. Agron., 105: 47-82.

55. Solaiman, Z.M., Murphy, D.V. and Abbott, L.K. (2011). Biochars influence seed emergence and early growth of seedlings. Plant and Soil 353: 273-287.

56. Solomon, D., J, Lehmann., J, Thies., T, Schafer,, B, Liang., J, Kinyangi., E, Neves., J, $\quad$ Petersen., $\quad$ F, Luizo. and J, Skjemstad. (2007). Molecular signature and sources of biochemical recalcitrance of organic C in Amazonian dark earths. Geochimica et cosmochimica Acta, 71: 2285-2298.

57. Stewart, C.E., Zheng, J., Botte, J. and Cotrufo, F. (2013). Co-generated fast pyrolysis biochar mitigates greenhouse gas emissions and increases carbon sequestration in temperate soils. Glob. Change. Biol. Bioenergy, 5: 153-164.

58. Suppadit, T., Phumkokrak, N. and Poungsuk, P. (2012). The effect of using quail litter biochar on soybean (Glycine max [L.] Merr.) production. Chil. J. Agric. Res., 72 (2) : 244-251.

59. Thornton, P.K., Ericksen, P.J., Herrero, M., and Challinor, A.J. (2014). Climate variability and vulnerability to climate change: A review. Glob. Chang. Biol., pp. 1-16.

60. Trompowsky, P.M., Benites, V.M., Madari, B.E., Pimenta, A.S., Hockaday, W.C. (2005) Characterization of humic like substances obtained by chemical oxidation of eucalyptus charcoal. Org. Geochem.., 36(11):14801489.

61. Tyron, E.H. (1948). Effect of charcoal on certain physical, chemical, and biological properties of forest soils. Ecol. Monogr., 18: 82-115.

62. Van Reewijk, L.P. (1992). Procedures for Soil Analysis. (3 Ed.). International Soil Reference Center (ISRIC), Wageningen, The Netherlands. 
63. Van Zwieten, L., Kimber, S., Morris, S., Chan, K. Y., Downie, A., Rust, J., Joseph, S. and Cowie, A. (2010). Effects of biochar from slow pyrolysis of papermill waste on agronomic performance and soil fertility. 20 Plant and Soil 327: 235-246.

64. Van Zwieten, L., Kimber, S., Morris, S., Downie, A., Berger, E., Rust, J.and Scheer, C. (2010a). Influence of biochars on flux of N2O and CO2 from ferrosol. Aust. J. Soil Res., $\quad$ 48: 555-568.

65. Walkey, A.J. and Black I.A. (1934). An examination of the Degtjareff method for determining soil organic matter and a proposed modification of the chromic acid titration method. Soil Sci., 37:29-38.

66. Wood, S.A., Jina, A.S., Jain, M., Kristjanson, P., and DeFries, R.S. (2014). Smallholder farmer cropping decisions related to climate variability across multiple regions. Glob. Environ. Chang., In Press.

67. Xu, G., Sun, J.-N., Shao, H.-B. and Chang, S.X.( 2014). Biochar had effects on phosphorus sorption and desorption in three soils with differing acidity. Ecol. Eng., 62: 54-60.

68. Yuan, J.H. and Xu, R.K. (2011). The amelioration effects of low temperature biochar generated from nine crop residues on an acidic ultisol. Soil Use Manage., 27: 110-115.

69. Yuan, J.H., Xu, R.K. and Zhang, H. (2011). The forms of alkalis in the biochar produced from crop residues at different temperatures. Bioresour Technol., 102:3488-3497.

70. Zhao, L., Cao, X., Mašek, O. and Zimmerman, A. (2013). Heterogeneity of biochar properties as a function of feedstock sources and production temperatures. J. Hazard. Mater.

71. Zheng, Wei., Sharma, B.K. and Rajgopalan, N. (2010). Using Biochar as a Soil Amendment for Sustainable Agriculture. Final Report Submitted to the Sustainable Agriculture Grant Program, Illinois Department of Agriculture. 